\title{
"REBELLIONS ARE BUILT ON HOPE"
}

\section{Women and Star Wars}

\section{Bridgitte Barclay}

\section{Keywords}

Star Wars, Women, Feminism

References to Star Wars -- such as the Rogue One quote, "Rebellions are built on hope" and images of Leia -- are common at women's marches since early 2017. It's perhaps no surprise that women who grew up in the 70s and 8os twisting their hair into Leia side buns and dreaming of befriending Ewoks find strength in Star Wars' female rebel characters in this era of retrograde global politics. It can feel quite a lot like fighting an evil empire lately. In fact, New York Times writer Alexandra Alter and others have noted the recent upsurge in global feminist science fiction with plotlines about resisting systems of gendered oppression. The what if question that drives science fiction enables speculations about current circumstances and enables us to think through resistant connections and trajectories. Feminists have long recognized this. The Empire Strikes Back scriptwriter Leigh Brackett wrote a good deal of midcentury science fiction with plots about science, rebellion, and gender. In this presentation, I want to explore the resistance and gendered hope inherent in Star Wars, focusing a bit on Brackett and then on Princess-turned-General Leia Organa and Rey.

It says something about our political and social climate that cultural productions with scientific underpinnings -- so all science fictions -- are resistant. Under Trump, the science of climate change, women's reproduction, basic understanding of gender and sexuality, environmental toxicity, and extinctions, for instance, have become resistant narratives. The U.S. National Parks Service started a trend of rogue twitter accounts. As NPR's Wynne Davis reported in January 2017:

'Rogue' accounts that have the look of those by real federal agencies are spreading like wildfire on Twitter. The AltUSNatParkService Twitter account has gained more than 1 million followers and inspired the creation of many more "unofficial resistance" accounts for specific national parks and other entities, including accounts like Rogue NASA and AltUSCIENCE FICTIONorestService. ${ }^{1}$ 
So, organizations based in science have to have rogue accounts. The National Parks Department is resistant. Take that in.

Trump's election and Carrie Fisher's death came close enough together to solidify Leia as an icon for the women's march. I was not alone in my November 2016 disbelief and despair when Trump was elected. The morning after the election, I cried as a jogged in the local park and passed three other people crying on the trails. My university sent an email to students that extra counselors would be available for those who felt marginalized and threatened by Trump's rhetoric -- those with disabilities, DACA students, those in the LGBTQIA community, people of color, women, survivors of sexual assault. When Carrie Fisher died a little over a month later, it hit hard. Many women (and others) were still numb, scared, and already thinking of how to resist. For many women my age losing Fisher -- losing Leia -- felt like losing the rebellion before it got started.

Leia is indicative of the long history that science fiction and feminism share. Science fiction is a genre that uses science to ask what if. In her introduction to the 1969 The Left Hand of Darkness, Ursula K. Le Guin writes that science fiction is a metaphor drawn from the sciences to imagine "alternative societies" and "alternative biologies"... a form of truth telling through lies. ${ }^{2}$ In Staying with the Trouble Donna Haraway uses SCIENCE FICTION as a way of figuring our current world. She writes that "science fiction, speculative fabulation, string figures, speculative feminism, science fact, so far" are all SCIENCE FICTION figures that she uses to discuss how we create a new world. ${ }^{3}$ She emphasizes the interdependence of speculation, science, and gender studies in understanding connections, writing, "Science fact and speculative fabulation need each other, and both need speculative feminism." 4 This expansion of SCIENCE FICTION makes clear the ways in which science, what if, and gender are all intertwined and open spaces for us to tell new stories. Resistant ones.

And, in fact, one of the queens of science fiction, Leigh Brackett, was the first writer on The Empire Strikes Back script, her last piece of writing before she died. Brackett was an accomplished scriptwriter and science fiction author. Among many other films, she was co-writer, with William Faulkner, on the 1946 detective film The Big Sleep, starring Lauren Bacall and Humphrey Bogart. She also wrote a number of westerns starring John Wayne, namely Rio Bravo. One of her more famous pieces of fiction, her 1955 novel The Long Tomorrow, has some of the same Western elements, elements we also find in The Empire Strikes Back with space cowboy Han, wild-west space settings, and themes of technology, power, and resistance. John Baxter writes that someone recommended Brackett to George Lucas for scriptwriting the Star Wars sequel but that Lucas didn't have a full understanding of who she was. When Lucas asked Brackett if she'd written for the movies, she recounted her films, and he responded after a pause, "Are you that Leigh Brackett? ... I called you in because you were a pulp science fiction writer!"5

Brackett may have glorified masculinity over femininity, and her Leia does not read as heroic as the Leia we all know, but Brackett's script contained some of the iconic elements of The Empire Strikes Back. Her script was a first draft, though, and she died before she could move into a second. Reports are that Lucas didn't like what Brackett sent, but despite this, her writing shaped the film. In Brackett's script Luke and Han ride snow lizards in the opening shot; the script is set on an ice planet with snow monsters; there is a frog-like master that teaches Luke; there is a notso-subtle love triangle among Luke, Han, and Leia, with a lot more making out than the film; and Leia and Luke are, thankfully given the making out, not brother and sister, but Luke does have a twin sister Nellith, who is also training to be a Jedi. 
The Leia we all know is rounder and fuller than the one Brackett wrote, thankfully, and Leia shaped at least one generation of women. I was almost three when Star Wars came out in 1977, and I don't remember seeing it the first time, but I was wearing those side buns by the time I was in first grade. My first piece of creative writing was set on a knock-off of Endor -- a young protagonist (spoiler, it was eight year old me) finds a lost civilization of teddy bears deep in the forest behind her house. I'm not a creative writer. I am the generation of Leia, though, and there are a lot of us who admired her fight -- strangling Jabba with the chains he placed on her, her elegant hologram attire, her blaster-wielding prowess. And those of us who admired that fight took up the resistance for her after 2016. As Hayley Gilmore, the artist who created the "Woman's Place is in the Resistance" posters says, "Leia resonates with many women because she is fierce, intelligent, charming, and powerful," one of the few female characters for a generation of girls in the 70 and 80 s (shout out also to She-Ra). ${ }^{6}$ Carrie Fisher's death at the end of 2016 cemented Leia's place in the twenty-first-century resistance.

General Leia Organa and the female leads that have followed Princess Leia in The Force Awakens and The Last Jedi have improved on female characters. Leia's sometimes flawed portrayal can be summed up in this quick story. My daughter Sophia, six at the time, told me she wanted to dress as Princess Leia for Halloween. Obviously, I realized I had achieved parenting perfection. Then she told me she wanted the bikini Leia. That was a no from me. But that was the version she meant when she said Leia and not the one I imagined when she said Leia. Bitch Magazine contributor Victoria Law writes about re-watching the original Star Wars with her fifteen-year-old daughter as they anticipated The Force Awakens release. Law realized she and her daughter saw Leia differently, writing that as a girl, Law saw Leia's mouthy stubbornness as strength. But she didn't consider that there were alternatives. While she found it normal that Leia would "assert herself, get blown off by the men around her, and have to argue her point," Law's daughter saw that as abnormal and frustrating, wondering why she couldn't be depicted with more authority. ${ }^{7}$ And better men.

Law's assertion is important in comparing young Leia to Leia as General and to Rey, for instance. General Organa leads a rebellion in part to save Kylo, while Luke and Han leave and abandon hope. And Rey isn't heterosexualized or objectified as Leia was. She's tough and loyal, fighting for justice without having to also be romantically partnered. She is the star of the film and the would-be replacement for Han and Leia's loser son. And, in fact, Rey's struggles with Kylo Ren, and resistance, may well be one of the most endearing facets of her character and one of the most familiar to many women.

In Kylo Ren, Rey is dealing with the First Order version of a male grad student who has read bell hooks once and wants to explain feminism to all of the women in the class. Mariana Plata writes for Psychology Today that Kylo Ren, in fact, displays Narcissistic Personality Disorder, so he is a good stand in for Trump's toxic masculinity with his lack of empathy, use of manipulation, and need for power. ${ }^{8}$ Kylo Ren's attempted manipulation of Rey, his silly wall-punching/ control panel sabering tantrums, and the impossible-to-forgive fact that he killed Han Solo make it unlikely he will turn good in the final episode. As Sam Wood writes in his Code Like a Girl article on toxic masculinity in The Last Jedi, we've seen Kylos before: "Young white men love this guy. He's tormented by his own whiteness, maleness, bourgeois status." 9 In other words, it's the old story of the privileged malaise of white hetero men unhappy with shared power. His underestimation of Rey and then his attempts to make her feel inferior, like she doesn't belong, are all too familiar to a lot of women. 
In fact, his antagonism of Rey because of her power is an insightfully honest depiction of privilege as an obstacle to the marginalized and an insightfully honest depiction of abuse. Wood points out that Kylo's biggest mistake is that he thinks Rey's story is his story. Her power his power. So, he tries to take it. In The Force Awakens, Kylo straps Rey down and enters her head, certainly a scene that echoes rape, saying, "You know I can take whatever I want." And he takes some of what he wants, reading her to play on her fears to try to break her. But she doesn't break. In fact, she terrifies Kylo, who is the ultimate Men's rights gatekeeper boy. He hangs out with the boss. Dresses the part. He's seen his grandpa in Return of the Jedi forty seven times, knows all the lines, and collects all of the movie paraphernalia.

Kylo Ren's condescension of Rey and psychological manipulation continues in The Last Jedi, but her resistance, and the resistance of others, offers hope. After Rey and Kylo Ren have a few intimate exchanges, Rey decides to go into the enemy ship to turn him. He stands by as Supreme Leader Snoke controls her body and enters her mind (again echoing rape). Though Kylo Ren kills Snoke and fights alongside Rey immediately after, he tries to shame her into joining him, demanding she say that her parents aren't heroes but sold her for drinking money when she was a child. As she cries, he says, as though in comfort, "You have no place in this story. You come from nothing. You're nothing. [...] But not to me. Join me" ${ }^{10}$ She fights and escapes, but her struggle in this scene -- realizing that she can't change Kylo -- is monumental.

I recognize that there is a Reylo (Rey and Kylo couplehood) movement for the next episode, but this scene of clear abuse is the one that convinces me that Star Wars wouldn't do that to us. There are too many important moments of women decisively saying "no" in The Last Jedi -- Rey fighting Snoke, Vice Admiral Holdo jumping to lightspeed to destroy Snope's ship, Rose screaming "no" as she helps Finn defeat Captain Phasma, Leia shooting Poe when he mutinies. With messages like Leia stopping Poe when he undermines Holdo's authority and like Yoda scolding Luke for looking to tradition instead of to Rey, the film condemns even the "good guys" for not seeing the women authorities in front of them.

So, Star Wars is important to a lot of women, not only for depictions of strong women for decades and recent depictions of toxic masculinity and abuse, but also for increasing diversity in recent films. The Rise of Skywalker will likely take into account issues of diversity as The Last Jedi did. Ricardo Lopez writes about diversity in recent Star Wars episodes, pointing out research by USC engineer Shri Narayanan using AI to gage diversity in film dialogue. The technology shows that in The Force Awakens, "the amount of female-driven dialogue more than tripled from the earlier films to nearly 28\%" and passed the Bechdel test with at least two women speaking to each other about something other than men. ${ }^{11}$ The Force Awakens was also more racially diverse than other films with "non-white speaking dialogue accounted for roughly $40 \%$ of all lines." ${ }^{12}$ Of course, in our current socio-political climate, we know how Loan Tran (Kelly Marie Tran), the Vietnamese-American actor who played Rose, and others of the diverse cast fared online. Tran writes for the New York Times about her online harassment from male "fans" and subsequent break from social media:

It wasn't their words, it's that I started to believe them. Their words seemed to confirm what growing up as a woman and a person of color already taught me: that I belonged in margins and spaces, valid only as a minor character in their lives and stories. ${ }^{13}$ 
Tran finishes her article writing that telling diverse stories is powerful and that she's "not giving up." She seems to pull from Rose's resistance in her closing, writing, "My real name is Loan. And I'm just getting started." 14 The women's marches have been pretty white (after white women messed up the vote), but Rose, Leia, and Rey give a diverse population hope.

So there is more work to do, but persistence and hope bring change. In her epilogue to our book Gender and Environment in Science Fiction, Christy Tidwell writes,

Through the processes of extrapolation and cognitive estrangement, the stories told in science fiction both reflect our reality and open avenues by which we can change our reality. And we need these possibilities. [...] Science fiction cannot singlehandedly undo [abuses of power], but it can provide language and narratives that work against them. ${ }^{15}$

Large communities of women embrace Star Wars because it helps change narratives and rewards the heroism of persistence and hope. Star Wars opens possibilities and play, and as Donna Haraway writes, one of the most dangerous stances in our contemporary world is, "a position that the game is over, it's too late, there's no sense in trying to make anything any better, or at least no sense having any active trust in each other in working and playing for a resurgent world" ${ }^{16}$. Rebellion is important, and a woman's place is in the resistance.

\section{Bibliography}

Anders, Charlie Jane, “The Mocked her 'Science Fantasy.' Then She Wrote Empire Strikes Back," iog. May 3, 2013, https://iog.gizmodo.com/they-mocked-her-science-fantasythen-she-wrote-empir-489586578.

Davis, Wynne. "It's Not Just the Park Service: 'Rogue’ Federal Twitter Accounts Multiply.” NPR. January 27, 2017.

https://www.npr.org/sections/alltechconsidered/2017/01/27/512007632/its-not-just-thepark-service-rogue-federal-twitter-accounts-multiply.

Gilmore, Hayley. A Woman's Place Is in the Resistance. 2017, Library of Congress, D.C.

Haraway, Donna. Staying with the Trouble: Making Kin in the Chthulucene. Durham: Duke

University Press, 2016.

Law, Victoria. “Two Generations Watch 'Star Wars' and See Princess Leia -- and Rey -- Two Different Ways.” Bitch Media. December 24, 2015.

https://www.bitchmedia.org/article/star-wars-leia-rey-feminist-compare-watching-moviewith-daughter.

Le Guin, Ursula K. The Left Hand of Darkness. New York: Ace Books, 2010. 
Lopez, Ricardo. "Women and Non-White Characters are Speaking More in Recent Star Wars Movies." Variety, December 8, 2017, https://variety.com/2017/film/news/star-warsdiversity-dialogue-bechdel-test-rogue-one-1202633473/.

Plata, Mariana, “3 Narcissistic Traits in Kylo Ren,” Psychology Today, December 19, 2017,

https://www.psychologytoday.com/us/blog/the-gen-y-psy/201712/3-narcissistic-traits-in-kyloren.

Star Wars: The Last Jedi. Directed by Rian Johnson (2017; Los Angeles: Walt Disney Pictures). Film.

Tidwell, Christy. "Epilogue.” In Gender and Environment in Science Fiction, edited by Christy Tidwell and Bridgitte Barclay (New York: Lexington Books, 2019), 203.

Tran, Kelly Marie. "I Won't Be Marginalized by Online Harassment.," New York Times. August 21, 2018. https://www.nytimes.com/2018/08/21/movies/kelly-marie-tran.html

Watercutter, Angela. “Princess Leia Gave the Women’s March a New Hope.” Wired. January 23, 2017. https://www.wired.com/2017/01/princess-leia-womens-march/.

Wood, Sam. "The Last Jedi, Toxic Maculinity, and Showing Your Place in All of This." Code Like a Girl. December 20, 2017. https://code.likeagirl.io/the-last-jedi-toxic-masculinityand-showing-your-place-in-all-this-bd16ffacdcfo.

\section{Notes}

${ }^{1}$ Davis, Wynne, “It's Not Just the Park Service: 'Rogue' Federal Twitter Accounts Multiply," NPR, January 27, 2017, https://www.npr.org/sections/alltechconsidered/2017/01/27/512007632/its-not-just-thepark-service-rogue-federal-twitter-accounts-multiply.

${ }^{2}$ Le Guin, Ursula K., The Left Hand of Darkness (New York: Ace Books, 2010), xviii-xix.

3 Haraway, Donna J., Staying with the Trouble: Making Kin in the Chthulucene (Durham: Duke University Press, 2016), 2.

${ }^{4}$ Haraway, Donna J., Staying with the Trouble: Making Kin in the Chthulucene (Durham: Duke University Press, 2016), 3.

5 Anders, Charlie Jane, "The Mocked her 'Science Fantasy.' Then She Wrote Empire Strikes Back," io9. May 3, 2013, https://iog.gizmodo.com/they-mocked-her-science-fantasy-then-shewrote-empir-489586578.

${ }^{6}$ Watercutter, Angela, "Princess Leia Gave the Women's March a New Hope," Wired, January 23, 2017, https://www.wired.com/2017/01/princess-leia-womens-march/. 
7 Law, Victoria, “Two Generations Watch 'Star Wars' and See Princess Leia -- and Rey -- Two Different Ways,” Bitch Media, December 24, 2015, https://www.bitchmedia.org/article/starwars-leia-rey-feminist-compare-watching-movie-with-daughter.

8 Plata, Mariana, “3 Narcissistic Traits in Kylo Ren,” Psychology Today, December 19, 2017, https://www.psychologytoday.com/us/blog/the-gen-y-psy/201712/3-narcissistic-traits-in-kyloren.

9 Wood, Sam, “The Last Jedi, Toxic Maculinity, and Showing Your Place in All of This," Code Like a Girl, December 20, 2017, https://code.likeagirl.io/the-last-jedi-toxic-masculinity-andshowing-your-place-in-all-this-bd16ffacdcfo.

${ }^{10}$ Star Wars: The Last Jedi, directed by Rian Johnson (2017; Los Angeles: Walt Disney Pictures), film.

${ }^{11}$ Lopez, Ricardo, "Women and Non-white Characters are Speaking More in Recent Star Wars Movies," Variety, December 8, 2017, https://variety.com/2017/film/news/star-wars-diversitydialogue-bechdel-test-rogue-one-1202633473/.

12 Lopez, Ricardo, "Women and Non-white Characters are Speaking More in Recent Star Wars Movies," Variety, December 8, 2017, https://variety.com/2017/film/news/star-wars-diversitydialogue-bechdel-test-rogue-one-1202633473/.

13 Tran, Kelly Marie, "I Won't Be Marginalized by Online Harassment," New York Times, August 21, 2018, https://www.nytimes.com/2018/08/21/movies/kelly-marie-tran.html.

14 Tran, Kelly Marie, "I Won't Be Marginalized by Online Harassment," New York Times, August 21, 2018, https://www.nytimes.com/2018/o8/21/movies/kelly-marie-tran.html

15 Tidwell, Christy, "Epilogue," in Gender and Environment in Science Fiction, eds. Christy Tidwell and Bridgitte Barclay (New York: Lexington Books, 2019), 203.

${ }^{16}$ Haraway, Donna J., Staying with the Trouble: Making Kin in the Chthulucene (Durham: Duke University Press, 2016), 3. 